\title{
Electrochemical Catalytic Cyclization Reactions using Environmentally
}

\section{Friendly Methodologies}

\author{
E. Duñach $^{\mathbf{a}}$, M. J. Medeiros ${ }^{\mathbf{b}^{*}}$, S. Olivero ${ }^{\mathbf{a}}$

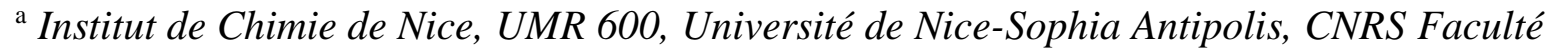 \\ des Sciences, Parc Valrose, 06108 Nice Cedex 2, France \\ ${ }^{b}$ Centro de Química, Universidade do Minho, Largo do Paço, 4704-553 Braga, Portugal
}

\begin{abstract}
The electrochemical intramolecular cyclisation of bromoalkoxylated derivatives $\underline{\mathbf{1}}$ was carried out using $\mathrm{Ni}(\mathrm{II})$ complexes as the catalysts in ethanol solutions by constant-current electrolysis in one-compartment cell in the absence of sacrificial anodes as an environmentally friendly system. The reduction of the substrates proceeds via one-electron cleavage of the carbon-bromine bond to form radical-type intermediates that undergo cyclisation to afford cyclic ethers in moderate to good yields.
\end{abstract}

Keywords: cyclization, nickel(II) complex, electroreduction, heterocycles, ethanol solvent 


\section{Introduction}

The formation of carbon-carbon bonds by radical cyclisations has become a highly valuable synthetic tool in organic chemistry, in particular for applications in the total synthesis of complex natural products. ${ }^{1,2,3}$ While organotin reagents used in stoichiometric and over-stoichiometric amounts have dominated synthetic procedures involving radical chemistry over the last decade ${ }^{2}$, problems associated with the product purification, price, and toxicity have stimulated the interest in the development of more user- and environmentally-friendly reagents. In addition to other synthetic methods, a convenient alternative to the tin hydride method to conduct the radical cyclisations can be the indirect electroreductive intramolecular cyclisation catalysed by transition-metal complexes. ${ }^{4}$

The furofuran moiety being an important subunit in a wide range of biologically active natural products, ${ }^{5,6}$ the nickel-mediated radical cyclisation has also been applied to the synthesis of substituted tetrahydrofurans. ${ }^{4}$ Most of these reported electrochemical cyclisations have been carried out in aprotic organic solvents at controlled-potential electrolysis in divided cell to avoid the anodic oxidation of species generated at the cathode. These reactions require membranes which should be stable in organic solvents, the use of a supporting electrolyte at a concentration as high as that of the substrate and complex electrochemical apparatus. ${ }^{7}$

Hence, most of these restrictions, notably the anolyte-catholyte separation, could be suppressed by the use of consumable anodes made of readily oxidized metal. ${ }^{8}$ This process is mainly characterized by its simplicity. At the laboratory scale, at least, a very simple 
electrical power source is used, making the method accessible at moderate cost. Scaling-up has also been successfully performed. However, during constant current electrolysis, the anodic metal becomes a stoichiometric reagent rather than simply an electrode.

Due to health, safety, and environmental issues the set-up of greener chemistry chemistry that efficiently utilises raw materials, eliminates waste, and avoids the use of toxic and or hazardous solvents and reagents in both products and processes is to be highlighted. The waste problem could be dramatically reduced by replacing methodologies employing stoichiometric reagents. Hence, in a perspective aimed at cleaner and catalytic electrosyntheses, we have explored the scope of cyclisation reactions using electrosyntheses in an undivided cell in the absence of sacrificial anodes.

In the present work, we investigated the catalytic reductive behaviour of ethyl 2bromo-3-(3',4'-dimethoxyphenyl)-3-propargyloxy-propanoate $(\underline{\mathbf{1 a}})$, ethyl 2-bromo-3(3',4'-dimethoxyphenyl)-3-allyloxy-propanoate $\quad(\underline{\mathbf{1 b}}), \quad$ ethyl 2-bromo-3-(3',4'methylenedioxophenyl)-3-propargyloxy-propanoate ( $\underline{\mathbf{1 c}})$ and 1-[2-bromo-2-phenyl-1-(prop2'-ynyloxy)ethyl]-4-methoxybenzene ( $\underline{\mathbf{1 d}})$, using $\mathrm{Ni}(\mathrm{II})$ complexes by constant-current electrolysis in ethanol. The constant-current electrolysis in an undivided cell in the absence of sacrificial anodes as environmentally friendly methodology in such reductive intramolecular cyclisation has not yet been reported.

\section{Experimental}

Reagents. - Each of the following chemicals was used as received: nickel(II) bromide (Aldrich, 98\%), 1,4,8,11-tetramethyl-1,4,8,11-tetraazacyclotetradecane (tetramethylcyclam, tmc, Fluka, 
97\%). Ethanol (EtOH), from Riedel-de-Häen, Analytical Reagent, was used as received. We purchased tetraethylammonium bromide $\left(\mathrm{Et}_{4} \mathrm{NBr}\right)$ with a purity of $98 \%$ from Fluka, tetra- $n$ butylammonium tetrafluoroborate $\left(\mathrm{Et}_{4} \mathrm{NBF}_{4}\right)$ with a purity of $99 \%$ from Aldrich and lithium trifluoromethanesulfonate $\left(\mathrm{CF}_{3} \mathrm{SO}_{3} \mathrm{Li}\right)$ with a purity of $99,99 \%$ from Aldrich; these electrolytes were stored in a vacuum oven at $80^{\circ} \mathrm{C}$ to remove traces of water. Deaeration procedures were carried out with zero-grade argon (Air Products). Published procedures were employed for the preparation of $[\mathrm{Ni}(\mathrm{tmc})] \mathrm{Br}_{2}{ }^{9}$ and of ethyl 2-bromo-3-(3',4'-dimethoxyphenyl)-3propargyloxy-propanoate $\quad \underline{\mathbf{1 a}}), \quad$ ethyl 2-bromo-3-(3',4'-dimethoxyphenyl)-3-

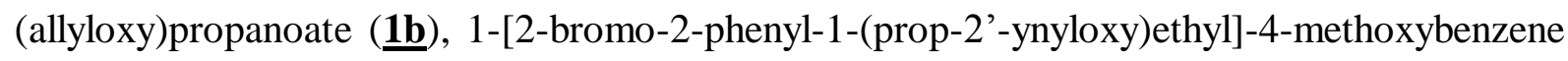
(1c) and ethyl 2-bromo-3-(3',4'-methylene-dioxophenyl)-3-(propargyloxy)propanoate $(\underline{\mathbf{1 d}})^{10}$.

Synthesis of 2-(3',4'-dimethoxyphenyl-3-ethoxycarbonyl-4-methylene-tetrahydrofuran

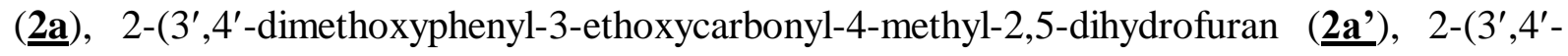
dimethoxyphenyl)-3-ethoxycarbonyl-4-methyltetrahydrofuran (흐), 2-(4'-methoxyphenyl)-4methylene-3-phenyltetrahydrofuran ( $\underline{\mathbf{2 c}}), 2-\left(3^{\prime}, 4^{\prime}\right.$-methylenedioxophenyl)-3-ethoxycarbonyl-4-

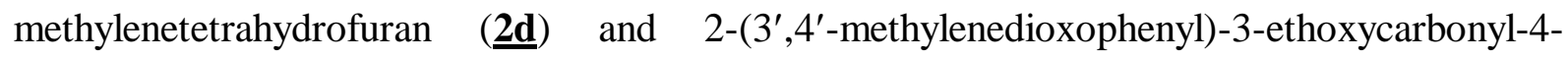
methyl-2,5-dihydrofuran $(\underline{\mathbf{2 d}})$ was based on the method published by McCague et al. ${ }^{11}$

Electrodes. - Electrodes for cyclic voltammetry were fabricated from 3-mm-diameter glassy carbon rods (Tokai Electrode Manufacturing Company, Tokyo, Japan, Grade GC-20) pressfitted into Teflon shrouds to provide planar, circular working electrodes with areas of 0.077 
$\mathrm{cm}^{2}$. Before use, the electrodes were cleaned with an aqueous suspension of $0.05-\mu \mathrm{m}$ alumina (Buehler) on a Master-Tex (Buehler) polishing pad.

All potentials are quoted with respect to a $\mathrm{Ag} / \mathrm{AgCl} / 3 \mathrm{M} \mathrm{KCl}$ in water reference electrode (-0.036 vs SCE).

Cells and Instrumentation. - Cyclic voltammograms were obtained with the aid of an AUTOLAB model PGSTAT12 potentiostat-galvanostat. The data from the above experiments were acquired and stored by locally written software, which controlled a data acquisition board installed in a personal computer. Cyclic voltammograms were recorded in a three-electrode, two-compartment cell as described in earlier publications. ${ }^{12}$

General electrosynthesis procedure. - The constant-current electrolyses were carried out in a single-compartment cell (capacity $50 \mathrm{~mL}$ ), such as described in Ref. 7, with a graphite rod or platinum grid as the anode (diameter $1 \mathrm{~cm}$ ) and a carbon felt cathode (apparent surface, 20 $\left.\mathrm{cm}^{2}\right)$ was formed into a cylinder around the counter electrode. EtOH $(50 \mathrm{~mL}), \mathrm{Et}_{4} \mathrm{NBr}\left(6 \times 10^{-3}\right.$ $\mathrm{M}), \mathrm{Ni}(\mathrm{tmc}) \mathrm{Br}_{2}\left(2.0 \times 10^{-3} \mathrm{M}\right)$ and bromoester $\left(1.0 \times 10^{-2} \mathrm{M}\right)$ were introduced in the cell under argon flow. The solution was stirred and electrolysed at room temperature, at a constant current of $30 \mathrm{~mA}$ (current density of $1.5 \mathrm{~mA} \mathrm{~cm}^{-2}$ and $7-9 \mathrm{~V}$ between the rod anode and the carbon felt cathode) until disappearance of the bromoether (checked by GC analysis of aliquots). Generally, 2-4 F/mol of starting material were necessary to achieve a complete 
conversion. Controlled-current electrolyses were carried out with the aid of a stabilized constant current supply (Sodilec, EDL 36.07).

${ }^{1} \mathrm{H}$ NMR data were recorded on a Varian Unity Plus 300 Spectrometer in $\mathrm{CDCl}_{3} ; \delta$ ppm were measured versus residual peak of the solvent. Identities of the electrolysis products were confirmed by means of a Hewlett-Packard 5890 Series II gas chromatograph coupled to a Hewlett-Packard 5971 mass-selective detector.

Identification and quantification of products. -The EtOH solvent was evaporated under vacuum, the reaction mixture was hydrolysed with $0.1 \mathrm{M} \mathrm{HCl}$ saturated with $\mathrm{NaCl}$, up to $\mathrm{pH} 1$ 2, extracted with $\mathrm{CH}_{2} \mathrm{Cl}_{2}$ and washed with $\mathrm{H}_{2} \mathrm{O}$. The dried $\left(\mathrm{MgSO}_{4}\right)$ organic layer was evaporated and the residue analysed by GC, GC-MS and ${ }^{1} \mathrm{H}-\mathrm{NMR}$. The crude residue was submitted to flash chromatography over silica gel (230-400 mesh) using ethyl acetate-light petroleum mixtures as the eluents. Cyclised compounds 2 were identified by NMR and mass spectrometry and compared to authentic samples, prepared independently according to ref. 14 . The compounds were identified by means of ${ }^{1} \mathrm{H}$ NMR spectrometry $\left(\mathrm{CDCl}_{3}\right)$ : (a) for $\underline{\mathbf{2 a}}, \delta 1.28$ $\left(3 \mathrm{H}, \mathrm{t}, J=7.0 \mathrm{~Hz}, \mathrm{OCH}_{2} \mathrm{CH}_{3}\right), 3.49(1 \mathrm{H}$, apparent ddd, $J=8.7,2.4$ and $2.4 \mathrm{~Hz}, 3-\mathrm{H}), 3.88$ $\left(3 \mathrm{H}, \mathrm{s}, \mathrm{OCH}_{3}\right), 3.90\left(3 \mathrm{H}, \mathrm{s}, \mathrm{OCH}_{3}\right), 4.22\left(2 \mathrm{H}, \mathrm{qABq}, J=7.0\right.$ and $\left.18.0 \mathrm{~Hz}, \mathrm{OCH}_{2} \mathrm{CH}_{3}\right), 4.50$ $(1 \mathrm{H}$, apparent dq, $J=13.2$ and $2.4 \mathrm{~Hz}, 5-\mathrm{H}), 4.65(1 \mathrm{H}$, broad apparent d, $J=13.2 \mathrm{~Hz}, 5-\mathrm{H})$, $5.11(1 \mathrm{H}$, apparent q, $J=2.4 \mathrm{~Hz}, \mathrm{C}=\mathrm{CH} H), 5.19(1 \mathrm{H}, \mathrm{d}, J=8.7 \mathrm{~Hz}, 2-\mathrm{H}), 5.20(1 \mathrm{H}$, apparent q, $J=2.4 \mathrm{~Hz}, \mathrm{C}=\mathrm{CHH}), 6.84\left(1 \mathrm{H}, \mathrm{d}, J=8.7 \mathrm{~Hz}, 5^{\prime}-\mathrm{H}\right), 6.90\left(1 \mathrm{H}, \mathrm{d}, J=1.8 \mathrm{~Hz}, 2^{\prime}-\mathrm{H}\right), 6.91$ (1H, dd, $J=8.7$ and $\left.1.8 \mathrm{~Hz}, 6^{\prime}-\mathrm{H}\right)$; (b) for $\underline{\mathbf{2 a}}$ ', $\delta 1.15\left(3 \mathrm{H}, \mathrm{t}, J=7.0 \mathrm{~Hz}, \mathrm{OCH}_{2} \mathrm{CH}_{3}\right), 2.19$ 
$\left(3 \mathrm{H}, \mathrm{d}, J=1.2 \mathrm{~Hz}, 4-\mathrm{CH}_{3}\right), 3.87\left(3 \mathrm{H}, \mathrm{s}, \mathrm{OCH}_{3}\right), 3.88\left(3 \mathrm{H}, \mathrm{s}, \mathrm{OCH}_{3}\right), 4.08(2 \mathrm{H}, \mathrm{qABq}, J=7.0$ and $\left.11.0 \mathrm{~Hz}, \mathrm{OCH}_{2} \mathrm{CH}_{3}\right), 4.72(1 \mathrm{H}$, apparent ddd, $J=1.2,3.6$ and $15.0 \mathrm{~Hz}, 5-\mathrm{H}), 4.89(1 \mathrm{H}$, apparent ddd, $J=0.9,5.7,15.0 \mathrm{~Hz}, 5-\mathrm{H}), 5.88-5.92(1 \mathrm{H}, \mathrm{m}, 2-\mathrm{H}), 6.83\left(1 \mathrm{H}, \mathrm{d}, J=8.1 \mathrm{~Hz}, 5^{\prime}-\right.$ H), $6.84\left(1 \mathrm{H}\right.$, broad s, 2'-H), $6.88\left(1 \mathrm{H}, \mathrm{dd}, J=8.1,1.8 \mathrm{~Hz}, 6^{\prime}-\mathrm{H}\right)$; (c) for $\underline{\mathbf{2 b}}, \delta 1.07(2.55 \mathrm{H}$, $\left.\mathrm{d}, J=6.9 \mathrm{~Hz}, 4-\mathrm{CH}_{3}\right), 1.18\left(0.45 \mathrm{H}, \mathrm{d}, J=6.6 \mathrm{~Hz}, 4-\mathrm{CH}_{3}\right), 1.25(0.45 \mathrm{H}, \mathrm{t}, J=7.0 \mathrm{~Hz}$, $\left.\mathrm{OCH}_{2} \mathrm{CH}_{3}\right), 1.28\left(2.55 \mathrm{H}, \mathrm{t}, J=7.2 \mathrm{~Hz}, \mathrm{OCH}_{2} \mathrm{CH}_{3}\right), 2.55(0.15 \mathrm{H}$, apparent $\mathrm{t}, J=9.0,8.7 \mathrm{~Hz}$, 3-H), 2.70-2.85 (1H, m, 4-H), $3.00(0.85 \mathrm{H}$, apparent dd, $J=9.0,7.8 \mathrm{~Hz}, 3-\mathrm{H}), 3.66(1 \mathrm{H}$, apparent dd, $\left.J=8.7,6.6 \mathrm{~Hz}, 5-\mathrm{H}_{\mathrm{a}}\right), 3.87\left(3 \mathrm{H}, \mathrm{s}, \mathrm{OCH}_{3}\right), 3.89\left(3 \mathrm{H}, \mathrm{s}, \mathrm{OCH}_{3}\right), 4.12-4.24(2 \mathrm{H}$, m, $\left.\mathrm{OCH}_{2} \mathrm{CH}_{3}\right), 4.28\left(1 \mathrm{H}, \mathrm{dd}, J=8.4\right.$ and $\left.6.6 \mathrm{~Hz}, 5-\mathrm{H}_{\mathrm{b}}\right), 5.05(0.15 \mathrm{H}, \mathrm{d}, J=9.0 \mathrm{~Hz}, 2-\mathrm{H}), 5.19$ $(0.85 \mathrm{H}, \mathrm{d}, J=7.8 \mathrm{~Hz}, 2-\mathrm{H}), 6.83\left(1 \mathrm{H}, \mathrm{d}, J=9.0 \mathrm{~Hz}, 5^{\prime}-\mathrm{H}\right), 6.88-6.92\left(2 \mathrm{H}, \mathrm{m}, 2^{\prime}-\mathrm{H}\right.$ and $6^{\prime}-$ $\mathrm{H})$; (d) for $\underline{\mathbf{2 c}}, \delta 3.64-3.70(1 \mathrm{H}, \mathrm{m}, 3-\mathrm{H}) ; 3.78\left(3 \mathrm{H}, \mathrm{s}, \mathrm{OCH}_{3}\right) ; 4.66(1 \mathrm{H}, \mathrm{dq}, \mathrm{J} 13.2$ and 2.4, 5$\left.\mathrm{H}_{\mathrm{a}}\right) ; 4.72(1 \mathrm{H}$, app q, $J=2.4, \mathrm{C}=\mathrm{C} \underline{\mathrm{HH}}) ; 4.79(1 \mathrm{H}, \mathrm{d}, J=9.3,2-\mathrm{H}) ; 4.84(1 \mathrm{H}$, broad d, $\mathrm{J}=$ 13.2, 5- $\left.\mathrm{H}_{\mathrm{b}}\right) ; 5.09(1 \mathrm{H}$, app q, $J=2.1, \mathrm{C}=\mathrm{CH} \underline{\mathrm{H}}) ; 6.81\left(2 \mathrm{H}\right.$, app d, $J=8.5,2^{\prime}-\mathrm{H}$ and 6'-H); 7.14

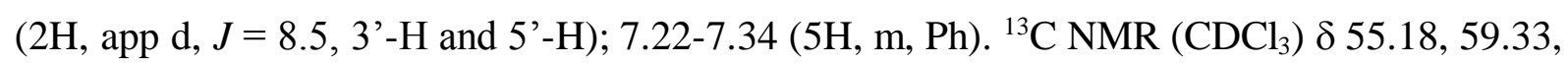
$71.96,88.26,106.04,113.62,126.86,127.43,128.48,129.07,132.05,139.10,152.82$, 159.20. Anal. Calcd for $\mathrm{C}_{18} \mathrm{H}_{18} \mathrm{O}_{2}$ (266.34): C, 81.17, H, 6.81. Found: C, 81.02; H, 6.78; (e) for $\underline{\mathbf{2 d}}, \delta 1.28\left(3 \mathrm{H}, \mathrm{t}, J=7.2 \mathrm{~Hz}, \mathrm{OCH}_{2} \mathrm{CH}_{3}\right), 3.42-3.47(1 \mathrm{H}, \mathrm{m}, 3-\mathrm{H}), 4.21(2 \mathrm{H}, \mathrm{qABq}, J=$ 7.2 and $\left.11.0 \mathrm{~Hz}, \mathrm{OCH}_{2} \mathrm{CH}_{3}\right), 4.49(1 \mathrm{H}$, apparent dq, $J=13.0,2.4 \mathrm{~Hz}, 5-\mathrm{H}), 4.63(1 \mathrm{H}$, br apparent d, $J=13.0 \mathrm{~Hz}, 5-\mathrm{H}), 5.10(1 \mathrm{H}$, apparent q, $J=2.4 \mathrm{~Hz},=\mathrm{CH}), 5.15(1 \mathrm{H}, \mathrm{d}, J=8.7$ $\mathrm{Hz}, 2-\mathrm{H}), 5.18(1 \mathrm{H}$, apparent q, $J=2.4 \mathrm{~Hz},=\mathrm{CH}), 5.96\left(2 \mathrm{H}, \mathrm{s}, \mathrm{OCH}_{2} \mathrm{O}\right), 6.77(1 \mathrm{H}, \mathrm{d}, J=8.0$ $\left.\mathrm{Hz}, 5^{\prime}-\mathrm{H}\right), 6.88\left(1 \mathrm{H}, \mathrm{dd}, J=8.0,1.8 \mathrm{~Hz}, 6^{\prime}-\mathrm{H}\right), 6.90\left(1 \mathrm{H}, \mathrm{d}, J=1.8 \mathrm{~Hz}, 2^{\prime}-\mathrm{H}\right) ;(\mathrm{d})$ for $\underline{\mathbf{2 d}}$ ', $\delta$ 
$1.16\left(3 \mathrm{H}, \mathrm{t}, J=7.2 \mathrm{~Hz}, \mathrm{OCH}_{2} \mathrm{CH}_{3}\right), 2.18\left(3 \mathrm{H}\right.$, apparent d, $\left.J=1.2 \mathrm{~Hz}, 4-\mathrm{CH}_{3}\right), 4.09(2 \mathrm{H}$, qABq, $J=7.2$ and $\left.10.8 \mathrm{~Hz}, \mathrm{OCH}_{2} \mathrm{CH}_{3}\right), 4.71(1 \mathrm{H}$, apparent ddd, $J=15.0,3.5,1.0 \mathrm{~Hz}, 5-\mathrm{H})$, $4.87(1 \mathrm{H}$, apparent ddd, $J=15.0,5.0,1.0 \mathrm{~Hz}, 5-\mathrm{H}), 5.83-5.87(1 \mathrm{H}, \mathrm{m}, 2-\mathrm{H}), 5.94(2 \mathrm{H}, \mathrm{s}$, $\left.\mathrm{OCH}_{2} \mathrm{O}\right), 6.76\left(1 \mathrm{H}, \mathrm{d}, J=8.0 \mathrm{~Hz}, 5^{\prime}-\mathrm{H}\right), 6.77\left(1 \mathrm{H}, \mathrm{d}, J=1.8 \mathrm{~Hz}, 2^{\prime}-\mathrm{H}\right), 6.82(1 \mathrm{H}, \mathrm{dd}, J=8.0$, $\left.1.8 \mathrm{~Hz}, 6^{\prime}-\mathrm{H}\right)$. These compounds were utilized as standards for the determination of gas chromatographic response factors.

Identities of the electrolysis products were confirmed by gas chromatograph / massselective detector: (a) for $\underline{\mathbf{2 a}}, \mathrm{m} / \mathrm{z}(70 \mathrm{eV}) 292, \mathrm{M}^{+}(23) ; 277,\left[\mathrm{M}-\mathrm{CH}_{3}\right]^{+}(0.6) ; 218,[\mathrm{M}-$ $\left.\mathrm{CO}_{2} \mathrm{C}_{2} \mathrm{H}_{5}-\mathrm{H}\right]^{+}(6) ; 165,\left[\left(\mathrm{CH}_{3} \mathrm{O}\right)_{2} \mathrm{C}_{6} \mathrm{H}_{3} \mathrm{CO}\right]^{+}(19) ; 126,\left[\mathrm{H}_{5} \mathrm{C}_{2} \mathrm{O}_{2} \mathrm{CC}_{4} \mathrm{H}_{5}\right]^{+}(51) ; 98,\left[\mathrm{C}_{5} \mathrm{H}_{6} \mathrm{O}_{2}\right]^{+}$ (100); (b) for 려', $m / z$ (70 eV) 292, $\mathrm{M}^{+}(100) ; 277,\left[\mathrm{M}-\mathrm{CH}_{3}\right]^{+}(16) ; 263,\left[\mathrm{M}-\mathrm{C}_{2} \mathrm{H}_{5}\right]^{+}(25)$; 215, $\left[\mathrm{M}-\mathrm{C}_{2} \mathrm{H}_{5} \mathrm{O}-\mathrm{CH}_{3} \mathrm{OH}\right]^{+}(49) ; 165,\left[\left(\mathrm{CH}_{3} \mathrm{O}\right)_{2} \mathrm{C}_{6} \mathrm{H}_{3} \mathrm{CO}\right]^{+}(66) ; 77,\left[\mathrm{C}_{6} \mathrm{H}_{5}\right]^{+}$(20); 29, $[\mathrm{COH}]^{+}(44) ;(\mathrm{c})$ for $\underline{\mathbf{2 b}}, \mathrm{m} / z(70 \mathrm{eV}) 294, \mathrm{M}^{+}(84) ; 279,\left[\mathrm{M}-\mathrm{CH}_{3}\right]^{+}(26) ; 265,\left[\mathrm{M}-\mathrm{C}_{2} \mathrm{H}_{5}\right]^{+}$ (69); 220, $\left[\mathrm{M}-\mathrm{CO}_{2} \mathrm{C}_{2} \mathrm{H}_{5}-\mathrm{H}\right]^{+}(10) ; 205,\left[\mathrm{M}-\mathrm{CO}_{2} \mathrm{C}_{2} \mathrm{H}_{5}-\mathrm{CH}_{3}-\mathrm{H}\right]^{+}$(35); 165, $\left[\left(\mathrm{CH}_{3} \mathrm{O}\right)_{2} \mathrm{C}_{6} \mathrm{H}_{3} \mathrm{CO}\right]^{+}(100) ; 29,[\mathrm{COH}]^{+}(16)$; (d) for $\underline{\mathbf{2 c}}, \mathrm{m} / \mathrm{z}(70 \mathrm{eV}) 266, \mathrm{M}^{+}(10) ; 129$, [M$\left.\mathrm{CH}_{3} \mathrm{OC}_{6} \mathrm{H}_{4} \mathrm{CHOH}\right]^{+}(100) ; 91,\left[\mathrm{C}_{6} \mathrm{H}_{5} \mathrm{CH}_{2}\right]^{+}(8) ; 77,\left[\mathrm{C}_{6} \mathrm{H}_{5}\right]^{+}$(18); (e) for $\underline{\mathbf{2 d}}, \mathrm{m} / z$ (70 eV) 276, $\mathrm{M}^{+}(35) ; 247,\left[\mathrm{M}-\mathrm{C}_{2} \mathrm{H}_{5}\right]^{+}(3) ; 202,\left[\mathrm{M}-\mathrm{CO}_{2} \mathrm{C}_{2} \mathrm{H}_{5}-\mathrm{H}\right]^{+}(18) ; 149,\left[\mathrm{CH}_{2} \mathrm{O}_{2} \mathrm{C}_{6} \mathrm{H}_{3} \mathrm{CO}\right]^{+}$(45); 126, $\left[\mathrm{H}_{5} \mathrm{C}_{2} \mathrm{O}_{2} \mathrm{CC}_{4} \mathrm{H}_{5}\right]^{+}(59) ; 98,\left[\mathrm{C}_{5} \mathrm{H}_{6} \mathrm{O}_{2}\right]^{+}$(100); (d) for $\underline{\mathbf{2 d}}$, $m / z(70 \mathrm{eV}) 276, \mathrm{M}^{+}(100) ; 261$, $\left[\mathrm{M}-\mathrm{CH}_{3}\right]^{+}(17) ; 247,\left[\mathrm{M}-\mathrm{C}_{2} \mathrm{H}_{5}\right]^{+}(34) ; 202,\left[\mathrm{M}-\mathrm{CO}_{2} \mathrm{C}_{2} \mathrm{H}_{5}-\mathrm{H}\right]^{+}$(82); 149, $\left[\mathrm{CH}_{2} \mathrm{O}_{2} \mathrm{C}_{6} \mathrm{H}_{3} \mathrm{CO}\right]^{+}(64) ; 77,\left[\mathrm{C}_{6} \mathrm{H}_{5}\right]^{+}(7) ; 29,[\mathrm{COH}]^{+}$(22). 


\section{Results and discussion}

Cyclic voltammetric behavior of $[\mathrm{Ni}(\mathrm{tmc})] \mathrm{Br} r_{2}$ in EtOH solutions in the absence and in the presence of bromoalkoxylated derivatives. - Cyclic voltammetry experiments showed that the $[\mathrm{Ni}(\mathrm{tmc})]^{2+} /[\mathrm{Ni}(\mathrm{tmc})]^{+}$redox couple $(\mathrm{tmc}=$ tetramethylcyclam $)$ gave a reversible $\mathrm{Ni}(\mathrm{II}) \mathrm{L} / \mathrm{Ni}(\mathrm{I}) \mathrm{L}$ peak in EtOH solutions containing 0.10 $\mathrm{M} \mathrm{Et}_{4} \mathrm{NBr}$ (Figure 1, curve A). The formal electrode potential of $[\mathrm{Ni}(\mathrm{tmc})] \mathrm{Br}_{2}$ in EtOH occurred at $-0.86 \mathrm{~V} v s$ $\mathrm{Ag} / \mathrm{AgCl}, 3 \mathrm{M} \mathrm{KCl}$.

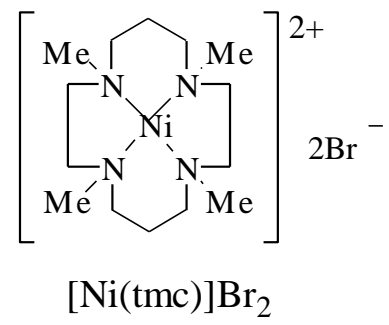

After addition of bromoether $\underline{\mathbf{1 c}}$ to the solution of $[\mathrm{Ni}(\mathrm{tmc})] \mathrm{Br}_{2}$ complex, the cathodic peak current, due to the formation of $[\mathrm{Ni}(\mathrm{tmc})]^{+}$complex, increases significantly and the anodic wave due to oxidation of $[\mathrm{Ni}(\mathrm{tmc})]^{+}$complex back to $[\mathrm{Ni}(\mathrm{tmc})]^{2+}$ complex is absent due to the chemical consumption of $[\mathrm{Ni}(\mathrm{tmc})]^{+}$complex (Figure 1, curve B). The catalytic current observed is due to the regeneration of $[\mathrm{Ni}(\mathrm{tmc})]^{2+}$ complex. Similar results were find for the other bromoethers $\underline{\mathbf{1}}$.

Hence, it can be established that an efficient electron-transfer between the electrogenerated $\mathrm{Ni}(\mathrm{I})$ complex and the bromoethers $\underline{\mathbf{1}}$ occurs, followed by substrate cyclisation, according to Equations 1-4. 
In the absence of $[\mathrm{Ni}(\mathrm{tmc})]^{2+}$, the bromoethers $\underline{\mathbf{1}}$ alone gave a reduction peak at potentials below $-1.50 \mathrm{~V}$ under the same experimental conditions as it can be seen for bromoether $\underline{1 \mathbf{c}}$ in Figure 1, curve C.

The reaction occuring at the anode was also explored. Figure 2 presents the cyclic voltammograms obtained for both electrolyte solutions, namely, 0.10 $\mathrm{M} \mathrm{Et}_{4} \mathrm{NBr} / \mathrm{EtOH}$ (curve A) and $0.10 \mathrm{M} \mathrm{Bu}_{4} \mathrm{NBF}_{4} / \mathrm{EtOH}$ (curve B). It was found that in a $0.10 \mathrm{M} \mathrm{Et}_{4} \mathrm{NBr} / \mathrm{EtOH}$ solution the oxidation of bromide anion at the anode occurs, leading to the formation of bromine (Figure 2, curve A). In contrast, in a $0.10 \mathrm{M} \mathrm{Bu}_{4} \mathrm{NBF}_{4} / \mathrm{EtOH}$ solution the oxidation of ethanol occurs (Figure 2, curve B).

Constant-current electrolyses of $[\mathrm{Ni}(\mathrm{tmc})] \mathrm{Br}_{2}$ in the presence of bromoalkoxylated derivatives. - Constant-current electrolyses of bromoalkoxylated compounds $\underline{\mathbf{1}}$ catalyzed by electrogenerated $[\mathrm{Ni}(\mathrm{tmc})]^{+}$complex was performed in a single-compartment cell using graphite and platinum as cathode/anode couple, instead of a consumable sacrificial anode. Reactions were carried out in EtOH containing $0.06 \mathrm{M} \mathrm{Et}_{4} \mathrm{NBr}$ at room temperature, under an inert gas.

The $[\mathrm{Ni}(\mathrm{tmc})] \mathrm{Br}_{2}$ complex used in 10-20 mol\% showed an efficient catalytic activity for the electrochemical cleavage of carbon-bromine bond of substrates $\underline{\mathbf{1}}$.

The preparative-scale electrolysis of substrates $\underline{1}$ generally consumed 2-4 F/mol of starting material; the reactions were followed by gas chromatography until conversions of 90$100 \%$. 
Compounds $\underline{\mathbf{2 a}}-\underline{\mathbf{2 d}}$ and isomers $\underline{\mathbf{2} \mathbf{a}^{\prime}}-\underline{\mathbf{2} \mathbf{d}^{\prime}}$ (see eq. 1-4) were obtained in the different cyclisation reactions and by-products $\underline{\mathbf{3 a}}-\underline{\mathbf{3 d}}$ were formed in very low amounts $(<5 \%)$ and were not isolated. The results obtained in these experiments are summarised in Table 1. Experimental parameters such as the ratio of bromoethers $\underline{1}$ to catalyst and the influence of nature of the electrodes were examined, to evaluate their effect on the product distribution.

The study was initiated by carrying out the electrolysis of $\underline{\mathbf{1 a}}$ in the presence of [Ni(tmc) $] \mathrm{Br}_{2}$ complex $(20 \mathrm{~mol} \%)$ in $\mathrm{EtOH}$ containing $0.06 \mathrm{M} \mathrm{Et}_{4} \mathrm{NBr}$ with graphite anode and a carbon fiber cathode. The electroreduction of $\underline{\mathbf{1 a}}$ (Eq. 1) led to the formation of the two cyclised furan derivatives, 2-(3',4'-dimethoxy)phenyl-3-ethoxycarbonyl-4-methylene-

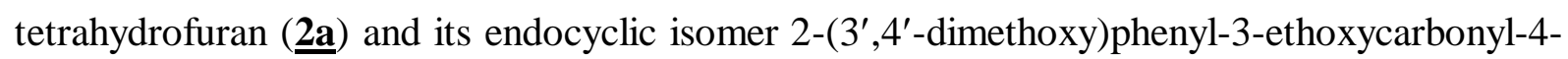

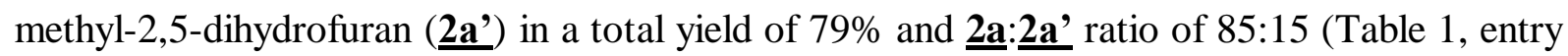
1) along with a small amount of the alkene $\underline{\mathbf{3 a}}(2 \%)$.<smiles>C#CC(OCC)[C@H](C(=O)OCC)c1ccc(OC)c(OC)c1</smiles>

Derivative ㅁa was obtained as a single trans stereoisomer according to NMR and by comparison with an authentic sample. The cyclic ether $\underline{\mathbf{2} \mathbf{a}}$, was issued from a double bond isomerisation from 르; $\underline{\mathbf{2 a}}$ being the expected primary cyclisation compound. During the electrolysis in a protic solvent such as $\mathrm{EtOH}$, some solvent reduction should generate ethoxide 
ion $^{13}$, able to effect the base-catalysed olefin isomerisation. It was independently tested in previous investigation that the formation of $\underline{\mathbf{2 a}}$ ' could be induced by an efficient electrogenerated base. ${ }^{14}$ These results are in agreement with related results reported by Medeiros et al. ${ }^{15}$ in EtOH using consumable anodes, in which the intramolecular cyclisation of analogous bromoalkoxylated derivatives led to the corresponding same cyclic ethers.

Next, the influence of the concentration of the catalyst was studied. It was found when the concentration of $[\mathrm{Ni}(\mathrm{tmc})] \mathrm{Br}_{2}$ complex diminished from 20 to $10 \%$, no significant effect on the total yield of the cyclic compounds $\underline{\mathbf{2 a}}$ and $\underline{\mathbf{2 a}}$ ' was observed (Table 1, entry 2). This result supports that the fact the electron transfert of the electrogenerated $[\mathrm{Ni}(\mathrm{tmc})]^{+}$to the substrate is efficient and that the ratios $[\mathrm{RBr}] /[\mathrm{Ni}(\mathrm{II})]$ used do not influence the reaction outcome.

The influence of the nature of the supporting electrolyte on the product distribution was also explored. Hence, the electrolysis of $\underline{\mathbf{1 a}}$ in the presence of $[\mathrm{Ni}(\mathrm{tmc})] \mathrm{Br}_{2}(10 \mathrm{~mol} \%)$ in EtOH containing $\quad 0.12 \quad \mathrm{M} \quad \mathrm{Bu}_{4} \mathrm{NBF}_{4} \quad$ or $\quad 0.12 \quad \mathrm{M}$ of TFSILi (lithium bis(trifluoromethanesulfonimide) as supporting electrolytes led to the formation of the cyclic compounds $\underline{\mathbf{2 a}}$ and $\underline{\mathbf{2} \mathbf{a}^{\prime}}$ in a total yield of $89 \%$ and $\underline{\mathbf{2 a}}: \underline{\mathbf{2} \mathbf{a}^{\prime}}$ ratio of $78: 22$ and $82 \%$ and $\underline{\mathbf{2 a}}: \underline{\mathbf{2 a}}$ ' ratio of 68:32 (Table 1, entries 3 and 4), respectively.

The electroreduction in protic media was extended to substrates $\underline{\mathbf{1 b}}-\underline{\mathbf{1 d}}$. The electrolysis of $\underline{\mathbf{1 b}}$ (Eq. 2) catalysed by electrogenerated $[\mathrm{Ni}(\mathrm{tmc})]^{+}$using a graphite/carbon fiber couple of electrodes afforded two stereoisomers of 2-(3',4'-dimethoxyphenyl-3ethoxycarbonyl-4-methyltetrahydrofuran $(\underline{\mathbf{2 b}})$ in $73 \%$ yield and a 75:25 ratio (Table 1, entry 
7), along with alkene $\underline{\mathbf{3 b}}(2 \%)$ as well as some the recovered $\underline{\mathbf{1 b}}(17 \%)$. According to NMR data, both stereoisomers present a trans ester to aryl configuration and differ by the cis-trans position of the methyl group. The main stereoisomer of $\underline{\mathbf{2 b}}$ presents the methyl group of the tetrahydrofuran ring in a cis position with respect to the ester group, according to 2D NMR experiments. $^{16}$

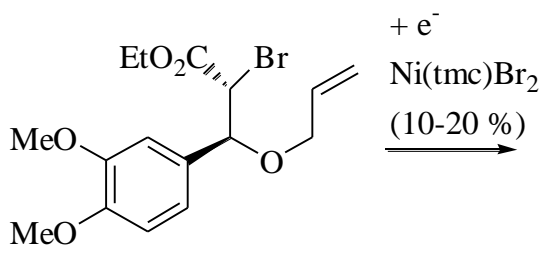

$\underline{\mathbf{1 b}}$<smiles>CCOC(=O)[C@H]1C(C)CO[C@@H]1c1ccc(OC)c(OC)c1</smiles>

$\underline{\mathbf{2 b}}$<smiles>CCOC(=O)/C=C/c1ccc(OC)c(OC)c1</smiles>

$\underline{3 \mathbf{a}}$

The influence of the nature of the anode was next explored. The change of graphite by platinum anode in the electrolysis of $\underline{\mathbf{1 b}}$ led to the formation of $\underline{\mathbf{2} \mathbf{b}}$ in a yield of $65 \%$ in a stereoisomeric 69:31 ratio (Table 1, entry 8) and of a small amount of alkene $\underline{\mathbf{3 b}}$ (4\%) and starting material $\underline{\mathbf{1 b}}(19 \%)$.

The electrolysis of $\underline{\mathbf{1 c}}$ (Eq. 3) was also carried out using graphite as anode and carbon fiber as the cathode. It was found that the reaction gave rise to the formation of $\underline{\mathbf{2 c}}$ as the major product in $68 \%$ (Table 1, entry 11 ) along with alkene $\underline{\mathbf{3 c}}$ as a minor product (11\%). 


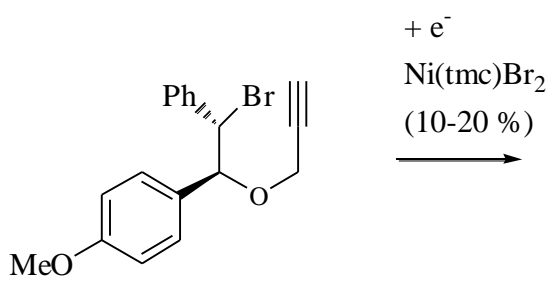

$\underline{1 c}$<smiles>C=C1COC(c2ccc(OC)cc2)[C@H]1c1ccccc1</smiles>

$\underline{\mathbf{2 c}}$<smiles>CCOC(=O)/C=C/c1ccc(OC)cc1</smiles>

$\underline{\mathbf{3 c}}$

Eq. 3

When the electrolysis of $\underline{\mathbf{1 d}}$ (Eq. 4) was performed with Pt/C as the couple of electrodes, the cyclic compounds $\underline{\mathbf{2 d}}$ and $\underline{\mathbf{2 d}}$ ' were obtained in a total yield of $74 \%$ and a $69: 31$ relative ratio (Table 1 , entry 12 ).

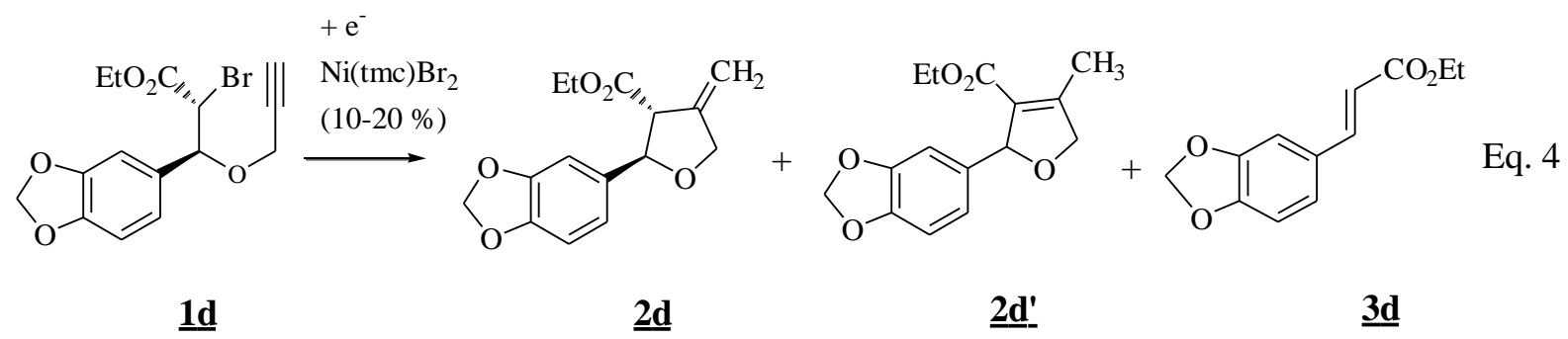

The influence of the concentration of the catalyst was also studied. It was found that when the concentration of $[\mathrm{Ni}(\mathrm{tmc})] \mathrm{Br}_{2}$ went from 20 to $1 \%$, it had little effect on the total yield of the cyclic compounds $\underline{\mathbf{2 d}}$ and $\underline{\mathbf{2 d}}$ ' (Table 1, entry 13) although the conversion was lower and $24 \%$ of starting material $\underline{\mathbf{1 d}}$ was recovered. This result supports that the ratio [RBr] / $[\mathrm{Ni}(\mathrm{II})]$ does not interfere on the reaction mechanism and the $[\mathrm{Ni}(\mathrm{tmc})]^{2+}$ complex can be used in a low catalytic amount.

It is interesting to compare the above experimental results with those obtained in previous research work on constant-current electrolyses using sacrificial anodes such as $\mathrm{Mg}$, 
$\mathrm{Zn}$ and $\mathrm{Al}$ in $\mathrm{EtOH}$ solutions containing $0.06 \mathrm{M} \mathrm{Et}_{4} \mathrm{NBr}^{11}$ (Table 1, entries 5,6,9,10,14,15). It can be observed that the total yields and the selectivities of the cyclic compounds are similar. Hence, it seems that the reaction can be performed using graphite or platinum as the anode in single-compartment cells, avoiding the use of sacrificial anodes.

For the $\mathrm{Ni}(\mathrm{II})$-catalysed cyclisation of $\underline{\mathbf{1 a}} \underline{\mathbf{1 d}}$ we propose the mechanism reported in a previous publication. ${ }^{15}$ A first $\mathrm{Ni}(\mathrm{II})$ reduction to $\mathrm{Ni}(\mathrm{I})$ occurs at $-0.86 \mathrm{~V}$ vs $\mathrm{Ag} / \mathrm{AgCl}$ with its further oxidative addition into the carbon-halogen bond of the substrate to form an intermediate of radical-type character. This intermediate has the ability to add to the double or triple bond and form a cyclised intermediate. The cyclised intermediate after reduction and proton abstraction from the electrolytic medium affords the reaction product recycling the $\mathrm{Ni}(\mathrm{II})$ complex.

\section{Conclusion}

In conclusion, we report here the use of an environmentally friendly methodology in $\mathrm{EtOH}$ as an alternative for the catalytic electrochemical radical-type cyclisation of unsaturated $\alpha$-bromoethers to the corresponding substituted tetrahydrofurans in moderate to high yields.

This investigation provides for the first time examples of the feasibility of preparativescale organic electrosynthesis in "green" solvents in the absence of dissolving metals in a catalytic procedure. Moreover, the simplicity and ease of application of the electrochemical method - working at constant-current electrolysis, in a one-compartment cell, with no sophisticated instrumentation and no expensive separator needed, at room temperature - 
should be emphasised and makes it a valuable synthetic tool and an interesting alternative to the stoichiometric use of organotin reagent in radical chemistry.

\section{Acknowledgements}

Most of this research was conducted while M.J.M. was a Visiting Scholar at University of Nice. In addition, we are grateful to Fundação para a Ciência e Tecnologia for financial support of this work, Project $n^{\circ}$ F-COMP-01-0124-FEDER-022716 (Ref ${ }^{a}$ FCT Pest C/QUI/UI=686/2011) FEDER-COMPETE-FCT-Portugal. 


\section{CAPTION FOR FIGURES}

Figure 1. Cyclic voltammograms recorded with a glassy carbon electrode (area $\left.=0.077 \mathrm{~cm}^{2}\right)$ at $200 \mathrm{mV} \mathrm{s}^{-1}$ in $\mathrm{EtOH}$ containing $0.10 \mathrm{M} \mathrm{Et}_{4} \mathrm{NBr}$ : (A) $1 \mathrm{mM}[\mathrm{Ni}(\mathrm{tmc})] \mathrm{Br}_{2}$; (B) $1 \mathrm{mM}$ $[\mathrm{Ni}(\mathrm{tmc})] \mathrm{Br}_{2}$ and $10 \mathrm{mM} \underline{\mathbf{1 c}} ;(\mathbf{C}) 2 \mathrm{mM} \underline{\mathbf{1 c}}$.

Figure 2. Cyclic voltammograms recorded with a glassy carbon electrode (area $=0.077 \mathrm{~cm}^{2}$ ) at $100 \mathrm{mV} \mathrm{s}^{-1}$ in EtOH containing: (A) $0.10 \mathrm{M} \mathrm{Et}_{4} \mathrm{NBr}$; (B) $0.10 \mathrm{M} \mathrm{Bu}_{4} \mathrm{NBF}_{4}$. 
Table 1. Electrochemical intramolecular cyclisation of $\underline{\mathbf{1 a}}-\underline{\mathbf{1 d}}(12 \mathrm{mM})$ catalysed by $[\mathrm{Ni}(\mathrm{tmc})] \mathrm{Br}_{2}$ in ethanol solutions containing $\mathrm{Et}_{4} \mathrm{NBr}(6 \mathrm{mM})$ at a carbon fiber cathode, $\mathrm{j}=0.15$ $\mathrm{A} \mathrm{dm}^{-2}$.

\begin{tabular}{|c|c|c|c|c|c|}
\hline Entry & Substrate & {$[\mathrm{Ni}(\mathrm{II})] / \mathrm{M}$} & Anode & $\begin{array}{c}\text { Products } \\
\text { (ratio of isomers) }\end{array}$ & $\begin{array}{c}\% \text { yield of } \\
\text { cyclised products }\end{array}$ \\
\hline 1 & $\underline{1 \mathbf{a}}$ & 2.4 & $\mathrm{C}$ & $\frac{\mathbf{2 a}}{(85: 15)}, \frac{\mathbf{2} \mathbf{a}^{\prime}}{15)}$ & 79 \\
\hline 2 & $\underline{1 \mathbf{a}}$ & 1.2 & $\mathrm{C}$ & $\frac{\mathbf{2 a},}{(74: 26)}$ & 86 \\
\hline $3^{(\mathrm{a})}$ & $\underline{1 \mathbf{a}}$ & 1.2 & $\mathrm{C}$ & $\frac{\mathbf{2 a}}{\left(78: \frac{\mathbf{2} \mathbf{a}^{\prime}}{22)}\right.}$ & 89 \\
\hline $4^{(\mathrm{b})}$ & $\underline{1 \mathbf{a}}$ & 1.2 & $\mathrm{C}$ & $\frac{\mathbf{2 a}}{(68: 32)}$ & 82 \\
\hline $5^{(\mathrm{c})}$ & $\underline{1 \mathbf{a}}$ & 2.4 & $\mathrm{Zn}$ & $\frac{\mathbf{2 a}}{(82: 18)}$ & 83 \\
\hline $6^{(\mathrm{a}, \mathrm{c})}$ & $\underline{1 \mathbf{a}}$ & 2.4 & $\mathrm{Mg}$ & $\frac{\mathbf{2 a}}{\left(40: \frac{\mathbf{2} \mathbf{a}^{\prime}}{60)}\right.}$ & 87 \\
\hline 7 & $\underline{1 \mathrm{~b}}$ & 2.4 & $\mathrm{C}$ & $\underline{(75: 25)}^{\left(\frac{2}{(d)}\right.}$ & 73 \\
\hline 8 & $\underline{1 \mathrm{~b}}$ & 1.2 & $\mathrm{Pt}$ & $\frac{\mathbf{2 b}}{(69: 31)}^{(\mathrm{d})}$ & 65 \\
\hline $9^{(\mathrm{c})}$ & $\underline{1 b}$ & 2.4 & $\mathrm{Mg}$ & $\frac{\mathbf{2 b}}{(93: 7)}^{(\mathrm{d})}$ & 61 \\
\hline $10^{(\mathrm{c})}$ & $\underline{1 \mathbf{b}}$ & 2.4 & $\mathrm{Zn}$ & $\frac{\mathbf{2 b}}{(93: 7)}^{(\mathrm{d})}$ & 65 \\
\hline 11 & $\underline{1 c}$ & 2.4 & $\mathrm{C}$ & $\underline{2 c}$ & 68 \\
\hline 12 & $\underline{1 d}$ & 2.4 & $\mathrm{Pt}$ & $\frac{\mathbf{2 d},}{\left(69: 3 \mathbf{d}^{\prime}\right.}$ & 74 \\
\hline $13^{(\mathrm{e})}$ & $\underline{1 d}$ & 0.12 & $\mathrm{C}$ & $\frac{\mathbf{2 d},}{(79: 21)}$ & 61 \\
\hline $14^{(\mathrm{c})}$ & $\underline{1 d}$ & 2.4 & $\mathrm{Mg}$ & $\frac{\mathbf{2 d},}{(61: 39)}$ & 70 \\
\hline $15^{(\mathrm{c})}$ & $\underline{1 d}$ & 2.4 & $\mathrm{Zn}$ & $\frac{\mathbf{2 d},}{(61: 39)}$ & 69 \\
\hline
\end{tabular}

(a) Carried out with $n$-Bu $\mathrm{Bu}_{4} \mathrm{NBF}_{4}$ as supporting electrolyte. (b) Carried out with TFSILi as supporting electrolyte.

(c) Data from Ref.[10]. ${ }^{(d)}$ Diastereomeric cis-to-trans ratio. ${ }^{(e)} \mathrm{j}=0.10 \mathrm{~A} \mathrm{dm}^{-2}$. 


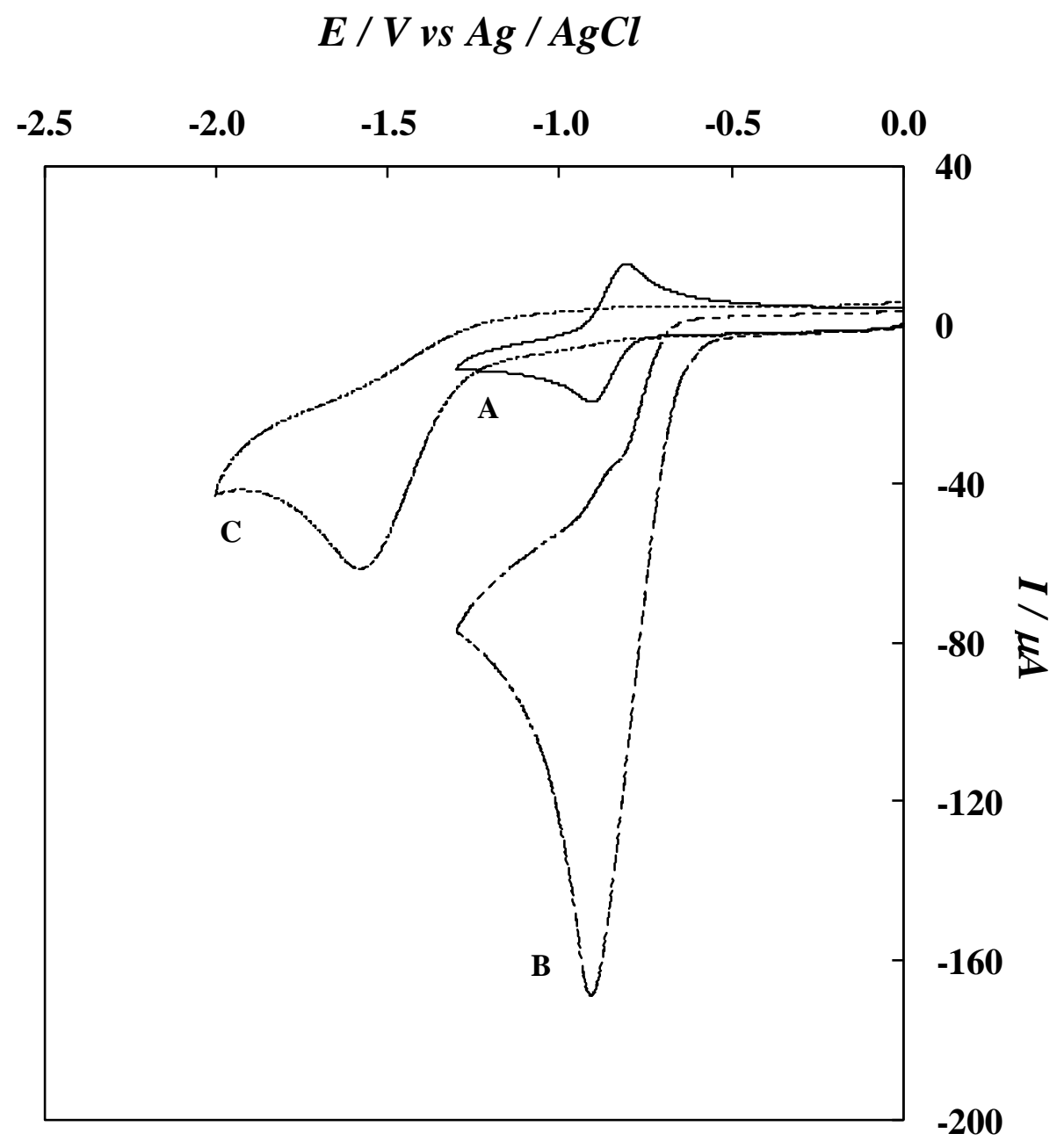

Figure 1 


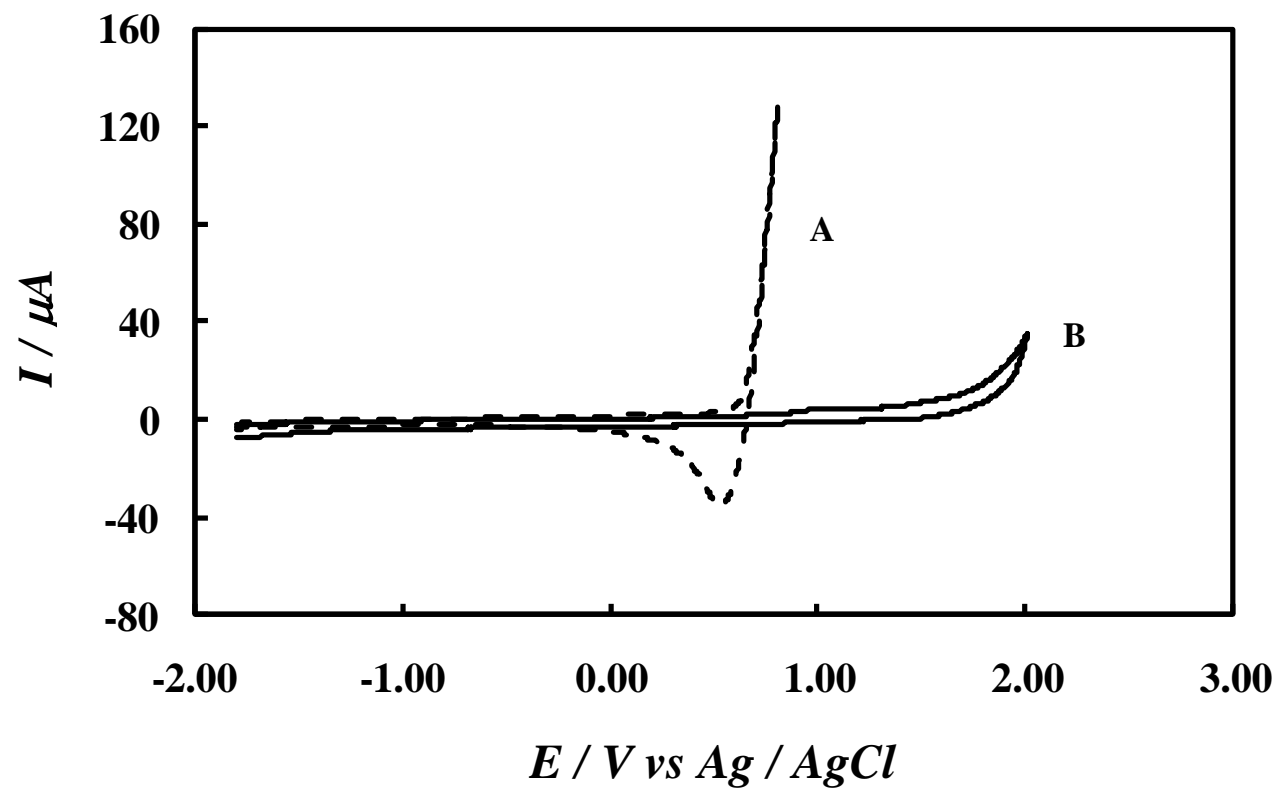

Figure 2 


\section{References}

1. B. Giese, B. Kopping, T. Gobel, J. Dickhaut, G. Thoma, and F. Trach, Org. React., 48 (1996)

2. B. Giese, Radicals in Organic Synthesis, Formation of Carbon-Carbon Bonds, Pergamon, Oxford (1986).

3. J. Fossey, D. Lefort and J. Sorba, Free Radicals in Organic Chemistry, Wiley, New York (1995).

4. E. Dunãch, M. J. Medeiros and S. Olivero, New J. Chem., 30, 1534 (2006).

5. S. C. Bobzin and J. D. Faulkner, J. Nat. Prod., 54, 225 (1991).

6. A. Merritt and S. V. Ley, Nat. Prod. Rep. 243 (1992) (and references therein).

7. D. Pletcher, A First Course in Electrode Processes, $2^{\text {nd }}$ Edition, RSCPublishing, Cambridge (2009).

8. J. Chaussard, J. C. Folest, J. Y. Nédèlec, J. Périchon, S. Sibille and M. Troupel, Synthesis, 5, 369 (1990).

9. B. Bosnich, M. L. Tobe and G. A. Webb, Inorg. Chem., 4, 1109 (1965).

10. S. C. Roy and S. Adhikari, Tetrahedron, 49, 8415 (1993).

11. R. McCague, R. G. Pritchard, R. J. Stoodley and D. S. Williamson, Chem. Commun., 2691 (1998).

12. K. L Vieira and D. G. Peters, J. Electroanal. Chem., 196, 93 (1985).

13. J. H. P. Utley and M. F. Nielsen, in Organic Electrochemistry, 4th ed. (Ed.: H. Lund, O. Hammerich), p. 1227-125 Dekker, New York (2001).

14. A. P. Esteves, D. M. Goken, J. L. Klein, M. A. Lemos, M. J. Medeiros and D. G. Peters, J. Org. Chem., 68, 1024 (2003).

15. E. Duñach, A. P. Esteves, M. J. Medeiros and S. Olivero, Green Chem., 8, 380 (2006).

16. E. Duñach, A. P. Esteves, M. J. Medeiros and S. Olivero, Tetrahedron Lett., 45, 7935 (2004). 